\title{
Chapter 12 \\ Exclusion from Home Care Services \\ in Central and Eastern European \\ Countries: A Focus on Hungary \\ and the Russian Federation
}

\author{
Zsuzsa Széman, Elena Golubeva, and László Patyán
}

\subsection{Introduction}

One of the challenges of care policies is to provide accessible and effective care that older adults can receive in their home. A report on long-term care (LTC) by the European Commission (2018) underlines that there is a clear trend on the part of the Commission and older people to prioritise home and community care provision. It also underlines that those in need of LTC in Southern (e.g. Cyprus, Greece, Malta, Portugal) and Eastern European countries (e.g. Bulgaria, Czech Republic, Estonia, Lithuania, Latvia, North Macedonia, Poland, Romania, Croatia, Slovenia, Slovakia), and in the UK, face insufficient availability of home care services. In recent years several countries within Central and Eastern Europe (CEE), among them Hungary, have restricted eligibility through austerity policies, while many others, such as the Russian Federation (Russia), remain focused on institutional care provision. Little evidence of intervention strategies relating to effective home care delivery in these contexts has been found within the international literature (Hirose and CzepulisRutkowska 2016). As much of the existing research focuses almost exclusively on Anglo-Saxon contexts and studies written in English, there are significant gaps in knowledge concerning home care provision, the potential of exclusion from this provision and regional variations across CEE countries. It is on this basis that this

\footnotetext{
Z. Széman $(\bowtie)$

Institute of Mental Health, Semmelweis University, Budapest, Hungary

e-mail: szeman.zsuzsanna@public.semmelweis-univ.hu

E. Golubeva

Department of Social Work and Social Security Northern (Arctic) Federal University,

Arkhangelsk, Russia

L. Patyán

Faculty of Health, Department of Gerontology, University of Debrecen,

Nyíregyháza, Hungary

(C) The Author(s) 2021

$\mathrm{K}$. Walsh et al. (eds.), Social Exclusion in Later Life, International Perspectives

on Aging 28, https://doi.org/10.1007/978-3-030-51406-8_12
} 
chapter explores exclusion from home care services in Central and Eastern Europe, ${ }^{1}$ focusing in particular on Hungary and Russia. The chapter concentrates on the presentation of research results available only in national languages. There are significant differences in relation to population size, territorial scope, culture and demographic structure. The proportion of those aged 65 and over in Hungary was $17.5 \%$ in 2014 (KSH 2014) while this figure was only $13.3 \%$ in Russia. By 2019 the figure increased to $19.3 \%$ (KSH 2019a) in Hungary while Russia will only reach a similar proportion (19.6\%) by 2031 (WHO, 2013). However, they have a common feature in that both countries have a post-socialist background. Furthermore, little has been documented about the evolution of home care policy in the two countries after this shift away from socialism, and little is known about whether or not older people face exclusion from home care services.

The chapter begins with a short review of national studies within CEE countries on areas related to social exclusion and exclusion from health and home care services. It then focuses on the case of Hungary and the ways in which exclusion can arise within its home care system. The case of Russia is then examined, and the experiences of older people accessing home care provisions. Finally, conclusions emerging across these two cases are presented.

\subsection{Exclusion from Home Care Services in Central and Eastern Europe}

Exclusion from home care services is not always clearly conceptualised. As a result, research on care services in Central and Eastern Europe sometimes draws on general concepts and trends of social exclusion in later life based on secondary analysis of large-scale EU surveys, such as the European Quality of Life Survey (Hrast et al. 2013) and the Survey of Health, Ageing and Retirement in Europe (SHARE) (Srakar et al. 2015). Data from the European Quality of Life Survey has shown significantly higher levels of social exclusion in later life in CEE countries than in the rest of Europe, in relation to access to health care, health status, and material deprivation (Hrast et al. 2013). According to the fifth wave of SHARE, LTC needs are higher in Eastern than in Western and Central European nations, but because family support is generally reported as being strong, exclusion may be reduced (in absolute terms at least) through family help (Laferrère and Bosch 2015). An analysis of the same data does, however, indicate that there is a connection between unmet LTC needs, social exclusion and welfare regimes. In this regard, according to Sraker et al. (2015) Eastern European (e.g. Estonia/Baltic country, Czech Republic, Slovenia/

\footnotetext{
${ }^{1}$ We use the definition of the OECD for CEE countries comprising Albania, Bulgaria, Croatia, the Czech Republic, Hungary, Poland, Romania, Slovakia, Slovenia, and the three Baltic States: Estonia, Latvia and Lithuania.
} 
Central Eastern European countries) welfare regimes lag comparatively behind other nations [also see Sumil-Laanemaa et al., Chap. 3, this volume].

There is also now a range of studies within the national scientific literatures of these countries that testify to the multifaceted exclusions of older people within CEE countries. A national exploratory study in Serbia noted the deterioration of the health and social status of women above 65 years (Petrusic et al. 2015). Konstantinova (2015) pointed out the increasing and unmet medical and social care needs of older people and people with disabilities in Bulgaria. A survey carried out by a charity service in the Ukraine found that the main concern of older people was their own health (Potischo 2015). In Romania, Ghenta and Mladen (2014) highlighted that the needs of Romanian older people for health and social services increased between 2009 and 2012, while key benefits designed to meet their needs had been decreased. To fill the gap, the role of non-governmental organisations was highlighted.

The observed social exclusion of older people in Slovenia included poor health and restricted access to health and social care, amongst other forms of disadvantage and deprivation. The limited availability of public services and spatially isolated locations result in lower access to services (Hrast et al. 2013). The low level of development of formal care settings in these contexts results in more pressure on family carers, while care allowances for caring families are generally low compared to national living standards. Available home care provision is also insufficient in CEE countries (Spasova et al. 2018) and policies barely emphasise the role of family caregivers and their support (Avram 2013; Hirose and Czepulis-Rutkowska 2016).

To further explore the challenges related to exclusion from home care services in Central and Eastern Europe, we will now compare and contrast the situations in Hungary and the Russian Federation.

\subsection{Exclusion from Home Care Services in Hungary}

In this section, we will first discuss current evidence concerning the general level of exclusion from care services in Hungary. We will then outline research concerning Hungarian care service legislation and the implications of the extant legislation and formal service provision for informal (family) caregivers.

Under the Social Welfare Act of 1993 local governments are obliged to provide social services for older people: home care, a maximum of four hours of daily help and meals on wheels. A per capita norm ${ }^{2}$ at that time was assigned to carry out these services. This law established the nationwide system of home care services and opened a future pathway for older people to access formal care provision. Persons over 60 years were entitled to receive home care in the social sector. However, this allowance did not cover the full costs of home care services and this often resulted

\footnotetext{
${ }^{2}$ The "per capita" norm refers to the institution being financed based on the number of recipients (according to the task).
} 
in unmet need. Certain settlements and regions, especially rural areas, remain unprovided for [also see Vidovićová et al., Chap. 17, this volume]. Despite the increase in the proportion of older people, healthy life years (HLY) lagged behind life expectancy. Even in recent years (2017) this gap persists: at age 65 years life expectancy was 14.4 years for men and 18.4 years for women (OECD 2019), while HLY was 6.9 years for men and 6.7 years for women (Eurostat 2019). Although the figures for HLY have improved slightly (to 6.9 and 7.4 years respectively in 2018) large numbers of both men and women still need some kind of help or care.

At the same time in 1995 one home carer cared for 3.6 old persons while this figure increased to 7.8 in 2012 (KSH 2012). It reached a peak of 9.5 in 2013 than slowly decreased back to 7.8 in 2018 (as the number of qualified carers slightly increased in 2018). Only 7\% of people aged 65 years and over have access to home care services (Gyarmati 2019) with demand for home care services considered to be two to three times greater than current supply. This demand is likely to only increase with the ageing of the population, and the ageing of the care workforce and difficulties in recruiting formal carers due to low prestige and salaries. In recent years, research has focused therefore on home care services in Hungary.

Rubovszky (2014), using a quantitative survey, showed a high level of exclusion from basic social services (including home care services) among older Hungarians (Rubovszky 2014). Similarly, a regional study in a remote region in North-Eastern Hungary in 2014 found that isolated people have less information about the availability of care and therefore even if they are entitled to formal provision, they do not have access to such services. This highlights the imperative need to rethink regional and local policy concerning home care provision (Patyán 2014). Results of focus group interviews in the Hungarian capital and in an East Hungarian town clearly showed that the legislation on home care provision introduced in 2015 excluded those with lower levels of care need, even if they do not have family carers who could fill this gap (Széman and Tróbert 2017a, 2017b). Inadequate home care legislation, and the implementation of that legislation results in disadvantages for remote rural regions with small and low-density populations. Regardless of the high proportion of older people living alone in these settlements, increased costs of the delivery of public care services to these regions and a shortage of care professionals at a local level have combined to establish a pattern of public service withdrawal from these areas. This translates into significant spatial inequalities in provision. Geographical and urban-rural differences result in unequal access and older people living in remote areas being more likely to be excluded from care services (see Geurs and Van Eck 2001; and Vidovićová et al., Chap. 17, this volume). A representative survey of general practitioners in 2016 found that the majority of survey respondents identified the need for the introduction of a more formal social care system that would tackle issues around home care and address these sorts of gaps directly (Tróbert and Széman 2018). 
Personal contributions by older people to home care service provision is limited and cannot exceed more than $20 \%$ of a person's pension. ${ }^{3}$ However, recipients usually have low incomes and therefore request services for only a very limited time even when this is far from sufficient (Patyán 2018). This draws attention to the link between low income and service exclusion. In addition, official care regulations governed by state regulations do not always define an appropriate level and quality of home care and as a result provisions are often time-limited. Moreover, regulations do not allow for professionals to develop an individual care plan in specific care situations. This type of care demand can exclude very frail older people from care services or it can result in a lower level of care provision than an older person's needs would require. Formal carers find it difficult to cope with these problems and this often leads them to mix their professional and personal roles and provide care in their free time, e.g. at the weekend when they offer additional privately paid home care service (based on private contracts) for those who are able to pay.

Out of the total number of family carers within Hungary, which is estimated at 400,000-500,000 (many of whom are older persons), only 20,000 receive a carer's allowance (Gyarmati 2019), which is around $16 \%$ of the average net salary (KSH 2019b). Tróbert (2019) found that close to 50\% of family carers between 51 and 60 years old faced a lack of support services and had reported increasing levels of care burden with a negative impact on their physical and mental state of health. Under the present legislation and service system many family carers (mainly older women) themselves face exclusion from social services. A qualitative research study involving 20 expert interviews within home care services recommends a care pattern which considers the capacity of a person's family carers to provide support at the beginning of care, and takes into account transportation, spatial inequalities and urban-rural differences (Patyán 2018). The new care pattern would result in appropriate levels of care provision and would decrease the care burden of family carers. Otherwise family carers would themselves be in need of significant health supports in the future in the absence of suitable financial and service assistance.

Summarising the results of these Hungarian studies: findings highlight the negative consequences of regulation, the unequal accessibility of services and the insufficiency of home care services. Evidence also highlights the consequences of service exclusion, particularly in relation to the growing pressure on family carers.

\subsection{Exclusion from Home Care Services in the Russian Federation}

Despite the fact that certain aspects of social exclusion of older people are widely considered within the Russian literature, there is no coherent approach to exclusion from home care services. Authors focus on peculiarities of regional exclusion

\footnotetext{
${ }^{3}$ https://net.jogtar.hu/jogszabaly?docid=99300003.tv
} 
practices (Chernyshkova and Andriyanova 2011; Maksimova et al. 2015; Golubeva and Khabarova 2019), models of exclusion explored in different regions (Maksimova et al. 2018), and strategies for social inclusion of older persons (Grigoryeva and Chernyshova 2009; Grishina 2013). Grigoryeva and Sidorenko (2019) noted that the concept of exclusion from social services vis-a-vis older persons in Russia has to take account of two major factors: the significant size of Russia's territory and the reluctance of Russian people, particularly older Russians, to leave their place of birth.

To give an overview of the relevant literature, we again start by providing a general account of exclusion from home care services in Russia. We then highlight aspects of the Russian care service legislation and discuss the role of informal (family) caregivers. According to Russian law (Federal Law 442), there are three forms of social services: inpatient social services; day care social services; home care services. Emphasis is placed on prevention in service design and implementation, with a focus on the needs of each individual within service delivery. In addition, the number of state programmes aimed at providing social support to citizens has been increased. On the other hand, the progress of society itself led to the emergence in the system of new social care organizations such as socially oriented nongovernmental organizations (NGOs), and private providers of social services. Since 2019, under the national project "Demography" there has been a phased introduction of a long-term care system aimed at developing and maintaining the functional abilities of the older population. This includes the incorporation of social and medical care at home, day care and inpatient care, as well as support for family carers.

According to the 2010 census, about $13 \%$ of Russian villages are designated as deserted and many others contain no more than ten inhabitants. This is due to outward migration of younger generations and younger people preferring to move to the urban areas in the central part of the country. About $80 \%$ of such villages are concentrated not in sparsely populated Siberia, but in the central regions of the country (Shcherbakova 2011). At the same time rural areas are considered to be characterised by a high level of integration of older people, which helps to create informal care networks (neighbours, friends), partially compensating for the insufficiency or absence of formal care services (Golubeva et al. 2017). The process of "ageing in place" (staying in one's own home and own local environment) is desirable for many older people, avoiding displacement and potential isolation in a new community. The situation regarding the accessibility of social care, including home and day care services for older people, in Russia is complicated due to the inaccessibility of key aspects of infrastructure, such as the low level of public transport in remote areas and restrictions in digital and mobile telecommunications access.

Only recently a new regulatory framework document "Evaluation of the effectiveness of state social assistance on the basis of a social contract" was adopted by the Ministry of Labour and Social Protection of the Russian Federation. The implementation of this policy, which allows for the assessment of service access by studying the "active measures of citizens" to overcome a "difficult life situation", can lead to changes or improve the material conditions of the family, including better access to services (Order 2016). Thus, when analysing home care services in the state system of social care in the Russian Federation, problems regarding insufficient monitoring of older people in need of social assistance should be resolved by 
application of this principle. In addition, most of the measures taken in the framework of the social protection of older people are largely aimed at eliminating factors and impediments of a difficult life situation, which do not allow an older person to perform everyday life activities (Grigoryeva and Sidorenko 2019).

Family care, as a part of informal care, plays a crucial role in home care service provision in Russia, but discussions on care policies are mainly focused on the responsibility of the state to provide support to carers in the family. Expanding family responsibility is becoming a key issue of care policy in Russia (Golubeva and Khabarova 2019). One of the traditional roles of the family in Russian society is to take care of its older members. Supported by cultural norms, religious beliefs, economic imperatives, and enshrined in informal sanctions, family care and care for older people is often one of the main mechanisms for caring for economically and socially weak, as well as physically dependent, family members (NAFI 2016). Almost every third Russian family includes an older individual who requires longterm care (30\%), and in most cases they are cared for by relatives. This problem is most acute for residents of small cities, towns and villages (35-40\%). The vast majority of Russians look after their older adult relatives on their own (94\%). Only $4 \%$ of Russians use the social services of the state system. Another $2 \%$ of respondents seek the services of private patronage services (home carers) (NAFI 2016).

The Strategy for Action on Citizens of the Older Generation in the Russian Federation until 2025 highlighted a trend associated with the view that "it is necessary to shape public opinion aimed at the active interaction of the family and relatives of senior citizens in relation to care and social services" in the conditions of the atomization of society, which reduced the role of the family and has contributed to increased prevalence of social isolation and loneliness (Order 2016, see p. 21). Such issues can lead to the exclusion of the older generation from public life and directly contribute to a deterioration of well-being and health. In Russian cultural mentality, the practice of placing older parents in residential homes, if there are children or other close relatives, is not very widespread because the micro-community of friends and relatives can condemn children for such action.

The significance of loneliness amongst older people in remote and rural areas of Russia has led the state to produce innovations in home care services. The foster families programme is one of the Russian governments responses to ensure that older people are being offered an efficient form of family-type social support in the context of increasing demands on state capacities and resources. The foster family is understood as a joint residence, comprising the household of a person who needs home (social) care and a person who wishes to provide that care to the older person, who is not a relative. A tripartite agreement is signed by the person performing care (carer), the older person and the local social services office. This programme is particularly prevalent in rural and remote areas of northern Russia that are characterised by heavy depopulation, ageing and difficulties in accessing institutional care services. The programme is based on a focus on the needs of older people living in remote communities and an approach that acknowledges the benefits of "ageing in place" (UNECE, 2017). The innovation is directly connected to the Russian home (social) care services expanding the possibilities of social services and family working together in remote areas. The implementation of innovative care practices, such 
as foster families - based not only on the capabilities of the state but also on the values and traditions of the older population in relation to family and health - can contribute to and ensure greater accessibility of various types of services that lead to the reduction of most social risks in old-age.

\subsection{Conclusion}

This chapter highlights that in Hungary and Russia research rarely directly considers exclusion of older people from home care services, but more typically examines the challenges of the system in health and social care systems in general, e.g. issues of demand, system limitations, and legislation. The case of Hungary clearly shows that macro-level policy (the new legislation of 2015) has not diminished exclusion and has even in some cases resulted in an intensification of the exclusion of older people from home care services. In Russian Federation on the other hand a macro-level policy decision (Order 2016) may have commenced the start of a positive trend to improve home care services in the long run.

In both countries, it is a major task for families and informal helpers to substitute formal home care provision and mitigate exclusion of older people from home care services. Russian Federation implemented a macro-level response, the foster family initiative. This pilot programme may help reduce the most serious shortage of care services in particular regions. This model emphasises the importance of actions at the local level and the need for a reflective and flexible local care policy. On the other hand, in Hungary there is no such type of macro-level policy although formal carers of home care services proposed a new care model: the involvement of the family as a necessary, integrated part of home care service. In Hungary a similar idea to the Russian home care system is taking shape, that is, to combine informal and formal care in a unified home care system, but it is yet to be seen how this will evolve and to what degree it will be implemented.

It is of vital importance to mitigate social exclusion of older people from home care services. The analysis here indicates the value of state led solutions by applying suitable legislation, which can be further elaborated at the mezzo (local government, care centres) and micro levels (family carers, informal helpers). An innovative approach could ease social exclusion from home care services of older people. This requires a focus on reforms to home care services and should also consider individual needs of ageing, or already old family carers.

\section{Editors' Postscript}

Please note, like other contributions to this book, this chapter was written before the COVID-19 pandemic of 2020. The book's introductory chapter (Chap. 1) and conclusion (Chap. 32) consider some of the key ways in which the pandemic relates to issues concerning social exclusion and ageing. 


\section{References}

Avram, S. (2013). Social assistance in central and Eastern Europe: Features and characteristics. Institute for Social and Economic Research, University of Essex https://www.iser.essex.ac.uk/ research/publications/working-papers/iser/2013-19.pdf. Accessed 5 Dec 2019.

Chernyshkova, Y. V., \& Andriyanova, Y. A. (2011). Potrebleniye meditsinskikh uslug pozhilym lyudyam v usloviyakh sotsial'nogo neravenstva [Consumption of medical services by elderly people in the context of social inequality (in the example of the Saratov region)]. Saratovskiy nauchno-meditsinskiy zhurnal, 7(1), 138-141.

European Commission. (2018). Challenges in long-term care in Europe - A study of national policies 2018 . https://ec.europa.eu/social/main.jsp?catId=738\&langId=en\&pubId=8128\&furtherP ubs=yes. Accessed 9 Dec 2019.

EUROSTAT. (2019). Healthy life years and life expectancy at age 65 by sex. https://ec.europa.eu/ eurostat/tgm/refreshTableAction.do?tab=table\&plugin $=1 \&$ pcode $=$ tepsr_sp320\&language $=$ en. Accessed 5 Dec 2019.

Geurs, K. T., \& van Eck, R. J. R. (2001). Accessibility measures: Review and applications. Evaluation of accessibility impacts of land-use transport scenarios, and related social and economic impacts. Biltoven: National Institution of Public and Health Environment.

Ghenta, M., \& Mladen, L. (2014). The partnership between public authorities and NGOs: An effective way of covering the need for social services in Romania. ICESBA http://icesba.eu/ RePEc/icb/wpaper/ICESBA2014_19GHENTA_P152-159.pdf. Accessed 4 Sep 2019.

Golubeva, E. Y., \& Khabarova, L. G. (2019). Family care as a tool for mitigating the social risks of the elderly people in remote areas. Advances in Gerontology, 9(3), 373-378. https://doi. org/10.1134/S2079057019030056.

Golubeva, E. Y., Khabarova, L. G., \& Soloviev, A. (2017). Priyemnaya semya kak novaya tekhnologiya sotsialnogo ukhoda $\mathrm{v}$ politike activnogo stareniya $\mathrm{v}$ otdalennyh severnyh territoriyah [Foster family as a new technology of social care in the policy of active ageing in remote northern areas]. Ekologiya cheloveka, 11, 42-46.

Grigoryeva, I. A., \& Chernyshova, S. P. (2009). Novyye podkhody k profilaktike sotsial'nogo isklyucheniya pozhilykh [New approaches to prevention of the social exclusion of the elderly]. Zhurnal sotsiologii $i$ sotsial'noy antropologii XII, (2), 186-196.

Grigoryeva, I. A., \& Sidorenko, A. V. (2019). Eldercare in transition(s): The special case of Russia. International Journal of Care and Caring, 3(1), 59-73 (15). https://doi.org/10.133 2/239788218X15411704353873.

Grishina, T. V. (2013). Kognitivnyye potentsial'nyye strategii issledovaniye sotsial'nogo vklyucheniya (illyustratsiya starshego vozrasta) [Cognitive potential strategies for the study of social inclusion (in the example of older age)]. Nauchnyy potentsial, 3(12), 84-88.

Gyarmati, A. (2019). Idősödés, idősellátás Magyarországon [Ageing and care for the elderly in Hungary], Budapest: Friedrich Ebert Stiftung, 7-10. http://library.fes.de/pdf-files/bueros/budapest/15410.pdf. Accessed 06 Dec 2019.

Hirose, K. \& Czepulis-Rutkowska, Z. (2016). Challenges in long-term care of the elderly in Central and Eastern Europe. Budapest: ILO DWT and Country Office for Central and Eastern Europe. https://www.ilo.org/wcmsp5/groups/public/\%2D\%2D-europe/\%2D\%2Dro-geneva/\%2D\%2D-sro-budapest/documents/publication/wcms_532427.pdf. Accessed 2 Oct 2019.

Hrast, F. M., Kopac, M. A., \& Rakar, R. (2013). Social exclusion of elderly in Central and Eastern Europe. International Journal of Social Economics, 40(11), 971-989. https://doi.org/10.1108/ IJSE-05-2012-0082.

Konstantinova, D. (2015). Mediko-sotsialni grizhi za vŭzrastni khora i khora s neudobstva chrez vizualizatsiya na meditsinski i sotsialni [Medico-social care for the elderly and people with disabilities as seen by medical and social care specialists]. Naucsni Trudove na University Russenskija, 8(3), 40-44. http://conf.uni-ruse.bg/bg/docs/cp15/8.3/8.3-6.pdf. Accessed 2 Oct 2019. 
KSH, Központi Statisztikai Hivatal. (2012). Szociális Statisztikai Évkönyv (Social Statistical Yearbook). Budapest: Központi Statistikai Hivatal.

KSH, Központi Statisztikai Hivatal. (2014). Szépkorúak és vének. Október elseje az idősek világnapja. (Olds and Oldest olds. First of October is a day for Older Adults) Statisztikai Tükör (Social Statistical Mirror). 2014, (103). https://www.ksh.hu/docs/hun/xftp/stattukor/idosek_ vilagnapja_14.pdf. Accessed 15 Jan 2020.

KSH, Központi Statisztikai Hivatal. (2019a). Magyarország népességének száma és életkor szerinti megoszlása 2019. január 1. [Population of Hungary and distribution by age on 1 January 2019]. https://www.ksh.hu/interaktiv/korfak/orszag.html. Accessed 9 Dec 2019.

KSH, Központi Statisztikai Hivatal. (2019b). Gyorstájékoztató. Keresetek 2019 január-szeptember [Flash Report. Earnings, January to September 2019]. https://www.ksh.hu/docs/hun/xftp/gyor/ ker/ker1909.html. Accessed 6 Dec 2019.

Lafferrère, A., \& Bosch, K. (2015). Unmet need for long-term care and social exclusion. https://pdfs.semanticscholar.org/581b/e670fbd5e4859fd8908d6a8c71c075f2fb64.pdf?_ $\mathrm{ga}=2.245380228 .107296117 .1570280916-1104196352.1570280916$. Accessed 4 Oct 2019 .

Maksimova, S. G., Noyanzina, O. Y., Maksimova, M. M., \& Shcheglova, D. K. (2015). Otsial'naya eksklyuziya lits starshikh vozrastnykh grupp: sotsial'no-ekonomicheskiye aspekty [Social exclusion of older age groups: Socio-economic aspects]. Vestnik Altayskogo gosudarstvennogo agrarnogo universiteta, 5(127), 180-184.

Maksimova, S. G., Noyanzina, O. E., \& Omelchenko, D. A. (2018). A model of social exclusion of elderly people in Siberian regions. Advances in Gerontology, 8(1), 58-63. https://doi. org/10.1134/S2079057018010083.

OECD. (2019). Data. Life expectancy at 65. https://data.oecd.org/healthstat/life-expectancy-at65.htm. Accessed 21 Feb 2020.

Order. (2016). Strategiya deistvii v interesah grazhdan starshego pokoleniya v Rossiiskoi Federatsii do 2025 [Strategy of action in the interests of the older generation in the Russian Federation until 2025]. Order of the Government of the Russian Federation, 05. 02.2016. - № 164-r. http:// base.garant.ru/71322816. Accessed 20 Sep 2018.

Patyán, L. (2014). Időskorúak közszolgáltatáshoz való hozzáférésének és szolgáltatáshasználatának jellemzöi az észak - alföldi régióban [The characteristics of elderly people's use of and access to public services in the North-East region]. Esély, 1, 62-78.

Patyán, L. (2018). Professzionális és családi gondozók viszonyrendszere az idősek otthoni gondozásában [The system of relationships between the professional and family caregivers in home care of the elderly]. Budapest: Eötvös Lóránd Tudományegyetem Társadalomtudományi Kar Szociológia Doktori Iskola. PhD dissertation. https://edit.elte.hu/xmlui/bitstream/handle/10831/41597/Disszert\%E1ci\%F3.pdf;jsessionid=1BB247616DA0F4DC2EBF255B5B1 6D0B3? sequence=1. Accessed 4 Oct 2019.

Petrusic, N., Todorovic, N., Vracevic, M., \& Jankovic, B. (2015). Financial abuse of older women in Serbia. Journal of Elder Abuse and Neglect, 27(4-5), 410-421. https://doi.org/10.108 0/08946566.2015.1094300. Accessed 1 Oct 2019.

Potischo, G. (2015). Age, peerson and society. http://www.tlu.org.ua/?p=2783. Accessed 26 Sep 2019.

Ruboszky, J. C. (2014). Házi segítségnyújtás talán egy kicsit másképp. [Home care - maybe a little bit differently]. Esély, 1, 4-30.

Shcherbakova, E. (2011). The number of rural settlements and urban-type settlements continues to decline (in Russian). Demoscope Weekly, 475-6. http://www.demoscope.ru/weekly/2011/0475/ lisa01.php. Accessed 4 Oct 2019.

Spasova, S., Baeten, R., Coster, S., Ghailani, D., Casas-Pena, R., Vanhercke, B. (2018). Challenges in long-term care in Europe. A study of national policies. Brussels: https://ec.europa.eu/social/ BlobServlet?docId=20225\&langId=en. Accessed 4 Oct 2019.

Srakar, A., Filipovič Hrast, M., Hlebec, V., \& Majcen, B. (2015). Social exclusion, welfare regime and unmet long-term care need: Evidence from SHARE. In A. Borsch-Supan, T. Kneip, 
H. Litwin, M. Myck, \& G. Weber (Eds.), Ageing in Europe - Supporting policies for an ageing society (pp. 189-198). Berlin: De Gruyter.

Széman, Zs, \& Tróbert, A. M. (2017a). A szociális innováció lehetőségei az idősgondozásban. [Possibilities of Social Innovation in long-term care]. Esély, 28(6), 45-62.

Széman, Zs., \& Tróbert, A. M. (2017b). Social innovation in the provision of Services in Longterm Care. European Journal of Mental Health, 12, 204-207.

Tróbert, A. M. (2019). Idős hozzátartozót gondozók leterheltsége [The burden of the caregivers taking care of elderly relatives]. PhD, Budapest: Semmelweis University http://semmelweis. hu/wp-content/phd/phd_live/vedes/export/trobertanettmaria.d.pdf. Accessed 4 Oct 2019.

Tróbert, A. M., \& Széman, Zs. (2018). Háziorvosok és idősellátás egy kérdőíves kutatás tükrében [General practitioners and eldercare as reflected in a survey by questionnaire]. Orvosi Hetilap, 159(8), 312-319.

UNECE. (2017). Policy brief on ageing. Older persons in rural and remote areas, No.18. https:// www.unece.org/population/ageing/policybriefs.html. Accessed 27 Sep 2019.

WHO. (2013). Russian federation national report. Study of global ageing and adult health (SAGE) Study 1. https://www.who.int/healthinfo/sage/en/. Accessed 10 Jan 2020.

Open Access This chapter is licensed under the terms of the Creative Commons Attribution 4.0 International License (http://creativecommons.org/licenses/by/4.0/), which permits use, sharing, adaptation, distribution and reproduction in any medium or format, as long as you give appropriate credit to the original author(s) and the source, provide a link to the Creative Commons license and indicate if changes were made.

The images or other third party material in this chapter are included in the chapter's Creative Commons license, unless indicated otherwise in a credit line to the material. If material is not included in the chapter's Creative Commons license and your intended use is not permitted by statutory regulation or exceeds the permitted use, you will need to obtain permission directly from the copyright holder.

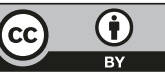

